\title{
入院患者持参薬を含む内服指示書作成システムの確立
}

\author{
金田亜季子 ${ }^{1}$, 大林恭子 $^{1}$, 阿部正樹 ${ }^{1}$, 飯塚恵子 ${ }^{1}$, 中村智德 ${ }^{12}$, 山本康次郎 ${ }^{* 12}$ \\ 群馬大学医学部附属病院薬斉部 ${ }^{1}$ \\ 群馬大学大学院医学系研究科臨床薬理学分野 2
}

\section{Development of a Computerized Medication Documentation System for Accurate Storage and Retrieval of Information on Drugs Prescribed Patients to Patients before Admission}

\author{
Akiko Kaneta ${ }^{1}$, Kyoko Obayashi ${ }^{1}$, Tadashige Abe ${ }^{1}$, Keiko lizuka ${ }^{1}$, \\ Tomonori Nakamura ${ }^{1,2}$ and Koujirou Yamamoto*1,2 \\ Department of Pharmacy, Gunma University Hospital, Japan ${ }^{1}$, \\ Department of Clinical Pharmacology, Gunma University Graduate School of Medicine, Japan ${ }^{2}$ \\ $\left[\begin{array}{l}\text { Received February 25, } 2010 \\ \text { Accepted May 20, } 2010\end{array}\right]$
}

\begin{abstract}
Many patients are taking drugs they have been previously prescribed or have obtained over the counter, and inaccurate information on their medication history commonly causes medication errors, which is a serious problem. Various strategies for reducing medication errors use information on medication history obtained immediately after admission. Such informa tion must be accurate and is an important means of preventing errors when prescribing new medications. With this in mind, we developed a computerized medication documentation system for generating medication orders that considers both drugs prescribed after admission and those that the patient has already been taking. A drug name search system using threecharacter agreement that is substantially the same as that used for prescription order entry systems was included to ensure accurate entry of the names of drugs prescribed before admission.

A fter the drug name search system was introduced, errors in new prescriptions, such as wrong strength, quantity, or dos age form, were reduced from $6.3 \%$ to $2.4 \%$. Prescriptions for wrong drugs decreased from $1.5 \%$ to $0.8 \%$. With our sys tem, a physician signs every prescription form to confirm the final medication order.

Our medication documentation system will be useful for providing accurate medication histories to nurses and physicians, and for preventing medication errors due unclear medication orders regarding drug name, strength, quantity, and formula tion.
\end{abstract}

Key words — medication documentation system, medication errors, prescription drugs, medication histories

\section{緒言}

入院患者の持参薬による投薬事故の発生を受け，2005 年 1 月に日本病院薬斉師会から「入院時患者持参薬に関 する薬斉師の対応について」が通知されたことにより， 各医療機関で持参薬の確認方法や持参薬情報の伝達手段 についてさまざまな検討がなされている．

入院患者の 60〜 80\% に持参薬があり ${ }^{1-6)}$, 1名分の持 参薬の鑑別にほぼ15〜30 分程度を要するので2, 4,7-9), 持参薬の確認には膨大な労力が必要である .この問題を 解決するために患者が入院手続きを行う持参薬確認コー ナーに2〜6名の薬剤師を配置したり ${ }^{10)}$, 専任の持参薬
チェック薬剂師を指名して各病棟の持参薬確認を支援す る11などの工夫がなされている．さらに，いったん薬剂 師が持参薬を回収したり ${ }^{8,9,12)}$, 患者に薬剂部に来てもら $い^{4,13)}$, 集中的に確認する工夫も見られる . 病棟担当者 が持参薬チェックを行うと薬剂管理指導の算定件数が激 減するので，医薬品情報担当者が持参薬チェックを担当 した例も見受(られる3).一方，病棟担当者がベッドサ イドで持参薬の鑑別を行う病院も多く2, $2,7,14)$, 光の後の 薬剂管理指導業務に反映させることができる点で優れて いると考えられる(1).

持参薬を調査した薬斉師は, その内容を反映させた持 参薬管理シートを作成し，これを利用して医師や看護師 に情報を伝達する . 入力時の支援として市販やオンライ 


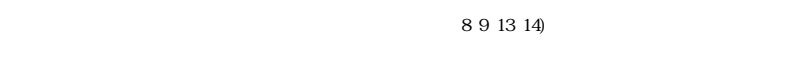
に入力する ${ }^{2,10}$ などの工夫もみられる . 持参薬の半数以 上が当該医療機関以外で処方されているとの報告もあ りの，入力過誤を防止するためには市販の全医薬品に対 応した入力支援システムの利用か望ましい2, 12,14).

一方，このようにして作成された持参薬の情報が医師 や看護師に確実に伝達し，正確に薬物療法に反映させる 方法については未だ十分な検討がなされていない，持参 薬チェックの結果を内服指示書へ転記する際の記載不備 が 26.2\% で認められており ${ }^{2)}$ ，内服指示書の作成に薬剂 師が直接関与しなければ，持参薬情報を患者への投薬に 正確に反映させることは難しい，一方で, 薬斉師が作成 した持参薬のみの管理シートを内服指示書として使用す ると，当該医療機関で処方された薬の指示書との併用に なり，薬歴管理や相互作用チェックが煩雑になるので好 ましくない，この問題を解決するためには，医師，看護 師も容易に利用でき, 持参薬と処方薬の情報を一体化し た内服指示書を薬剂師の管理下で随時作成できるシステ ムの構築が必須である.

群馬大学医学部附属病院(以下, 当院と略す)では, 2003年 4 月より処方オーダシステムを反映させた内服 指示書を作成するシステムを構築し，医師，看護師およ び薬斉師の実施確認を記録する内服指示書として運用し ている.指示書を週 1 回更新し，随時変更した内容は医 師が直接指示書に追記することで，誤った指示による医 療過誤を防止してきた .さらに，2004年 9 月に処方薬 と同樣に持参薬を内服指示書に反映するために持参薬入 カシステムとして，院内未採用の持参薬もフリーターム
で入力できる持参薬入力ボックス機能を追加した．しか し，フリーターム入力では医薬品名を正確に入力するこ とが困難であり，医師の負担も大きいので，医師による 指示出しが徹底されなかった. 2007 年 6 月処方オーダ システムを反映させた内服指示書を指示書として正式に 運用することを決定し，安全管理室を通じて診療科に徹 底を図った .2009年 1月の病院情報システム更新時に， 持参薬入力時にすべての薬価収載医薬品を 3 文字一致検 索で入力可能にした . 光こで, 医師による指示出しの徹 底, 市販されている全医薬品に対応した入カシステムの 導入，薬冏師による持参薬情報の入力により，指示出し 指示受けの徹底および入力情報の精度の改善を試みた．

\section{方法}

1. 内服指示書作成システムの構成

内服指示書作成システムは病院情報システムの一部で ある電子カルテシステムの一部として構築し, 病院の帳 票として出力ができる . 持参薬入カシステムは電子カル テシステムの一部として構築し, 持参薬データは病院情 報システムで処方データと統合され，内服指示書へ記載 される.持参薬マスターデータ(以下，DICSデータと略 す)はサブシステムである薬剂管理指導システムで管理 し，電子カルテシステムから参照する(図 1).

処方オーダでは処方マスターに登録された採用医薬 品, 持参薬情報はInfocom 社のDICSデータに登録され た市販の全医薬品の入力が可能であり，いずれも3文字 一致検索により入力できる .

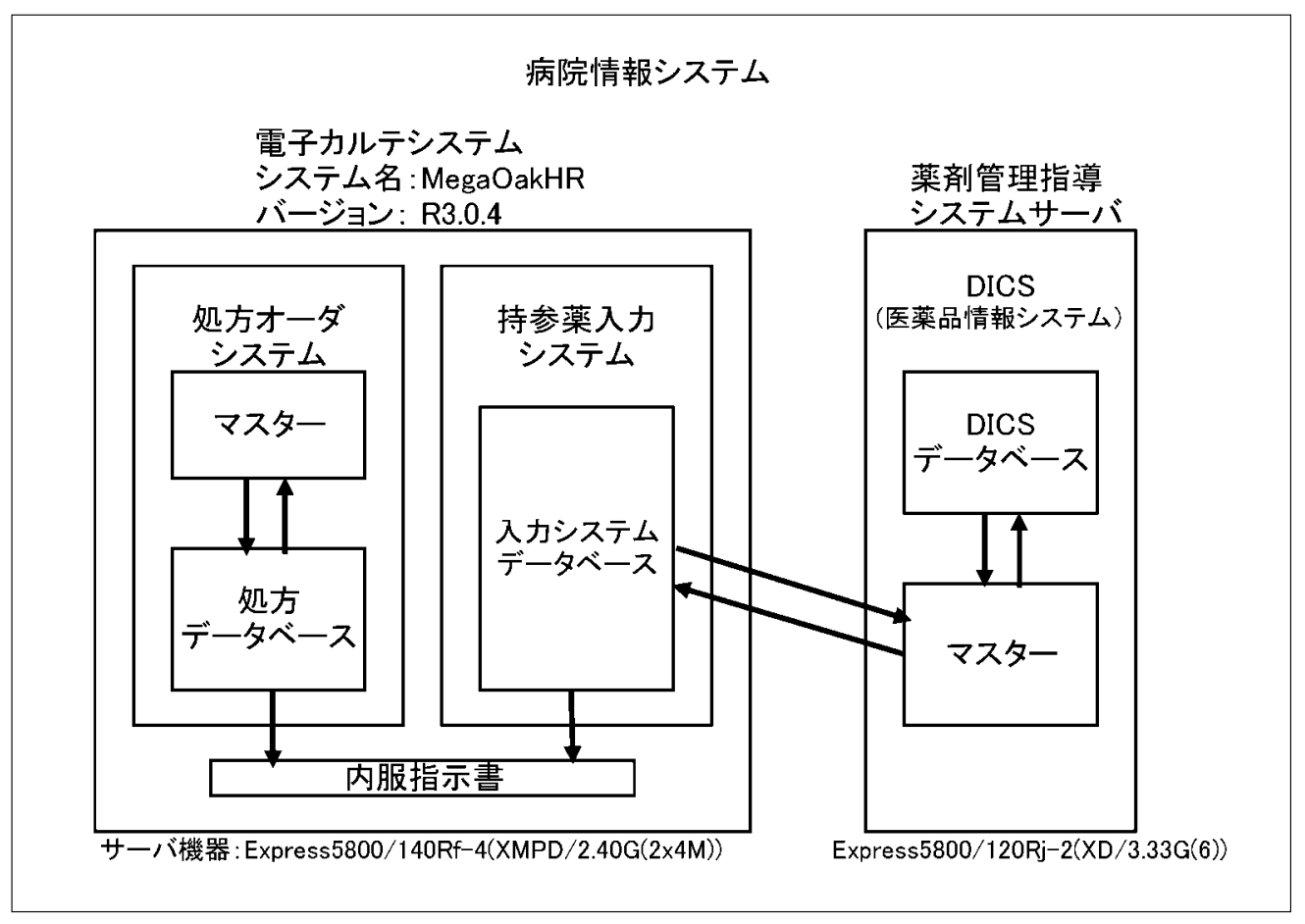

図 1 . 病院情報システムにおける内服指示書作成システムの構成 
2. 持参薬の確認と内服指示書の運用

2003年 4 月より処方オーダシステムを反映させた内 服指示書を作成するシステムを構築し，2004年 9 月に 処方薬と同樣に持参薬を内服指示書に反映するために持 参薬入カシステムを導入した .

患者の入院日に, 病棟に常駐する薬斉師が持参薬を鑑 別し，患者との面談により，処方歴やお薬手帳の記載と 比較しながら実際の用法用量や服薬状況, 市販薬やサプ リメントの有無，アレルギー歴なども確認する．また， 入院後も使用を継続する持参薬については医師が自ら， または医師の依頼を受けた薬阁師が，持参薬情報を病院 情報システムに入力する(図 2).なお，薬名は 3 文字一 致検索の薬斉選択一覧より選択し，用法は処方オーダシ ステムと同樣の用法一覧から選択することができる．頓 用指示の処置薬等も同樣に入力した後, 医師が内服指示 書(図 3)を出力する.

持参薬，頓用指示薬および処方薬をすべて反映した 1 週間分の内服指示書が出力されるので, 担当医が指示内 容を確認して署名することにより指示出しとする . 内服

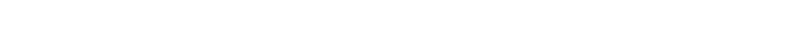
内容を確認した上で指示受けの署名をし，指示書の運用 を開始する.与薬の際は, 薬を準備したスタッフ, 配薬

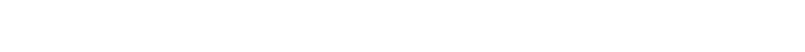
れ署名し，実施確認とする．1週間使用した内服指示書 はスキャナで電子カルテに取り込み保存する．

処方変更が発生した場合は医師が手書きで指示書に記 載して署名するとともに，指示受け者も署名して確認を 行う. 同時に処置薬や処方オーダの入力内容も変更する
ことにより次週の内服指示書に変更内容が反映される . 指示書の記載内容が実際の服薬と一致しない場合は薬剤 師が修正入力をして医師の確認を求める .

\section{3. 持参薬入カシステムの変更による持参薬情報の精度 の改善}

システム改変直前の 2008年 11 12月および改変直後 の 2009年 1 2 月で, 祝日を含まない4 4週間の内服指示 書の記載について，指示書の記載内容と薬剂師が確認し た実際の服薬状況を比較することにより，指示間違えを 確認するために持参薬の規格の入力不備および薬名や用 法用量などの誤入力率を調査した .

システム改善前後をX²検定により比較し，危険率 5 \%未満を有意水準とした。

\section{4. 医師による指示出しの徹底}

診療科が独自の内服指示書を作成したり，入院時に医 師の確認か間にあわず医師の署名がないまま内服指示書 の運用が開始された後に医師が確認署名を行っていた診 療科があったため院内で統一した運用を確実に行えてい なかった . 弚こで，2007年 6 月処方オーダシステムを 反映させた内服指示書を指示書として正式に運用するこ とを決定し, 薬斉師が医師による指示出しの実施率を確 認し，医師の指示出しを徹底するために医療安全管理室 から各診療科に対して通知を行った，弚の後の実施状況 を確認するため，2009年 3 月の 2 週間における内服指 示書への署名の実施率を調査した .

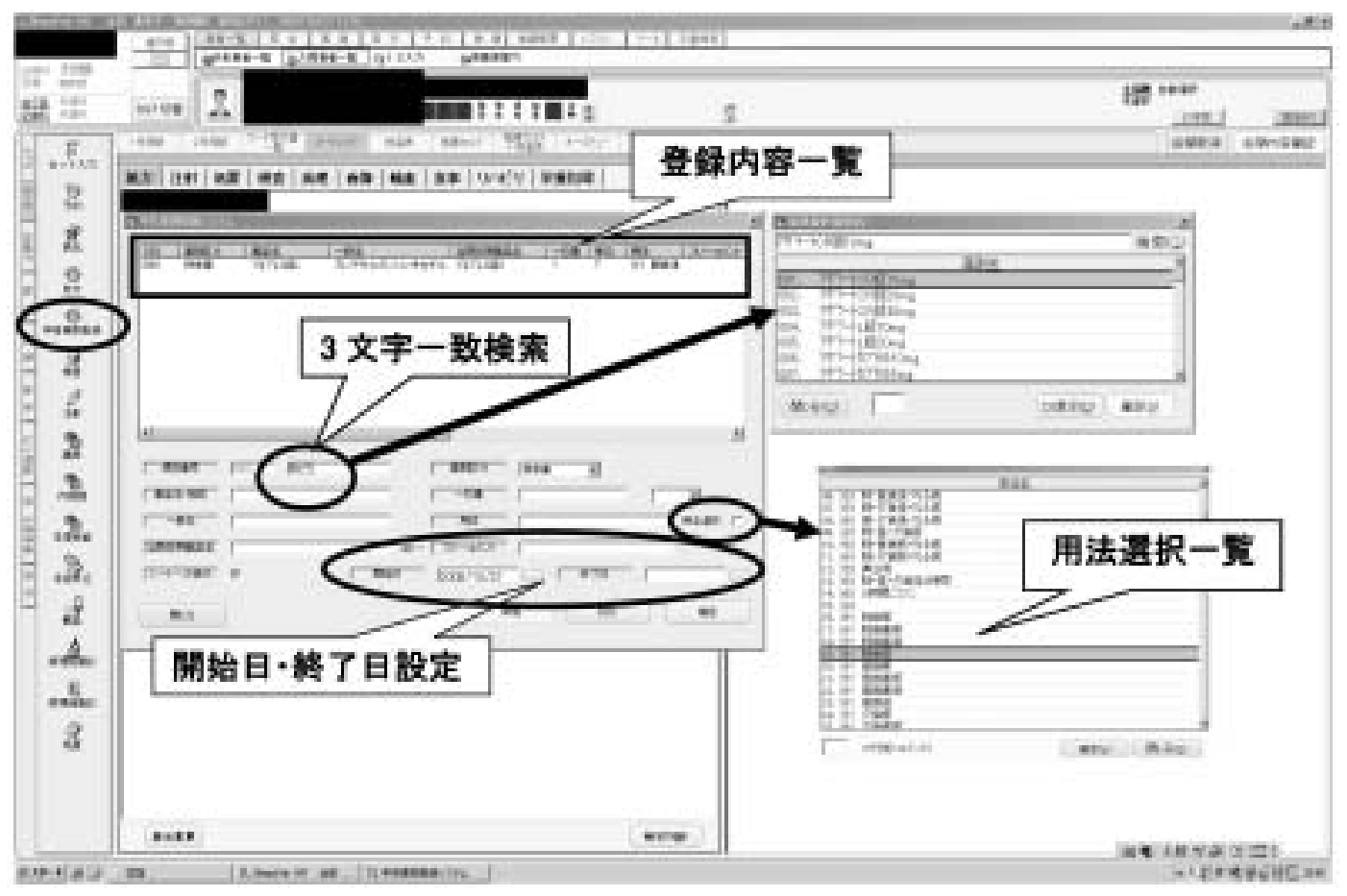

図 2 . 持参薬入カシステムの実際 


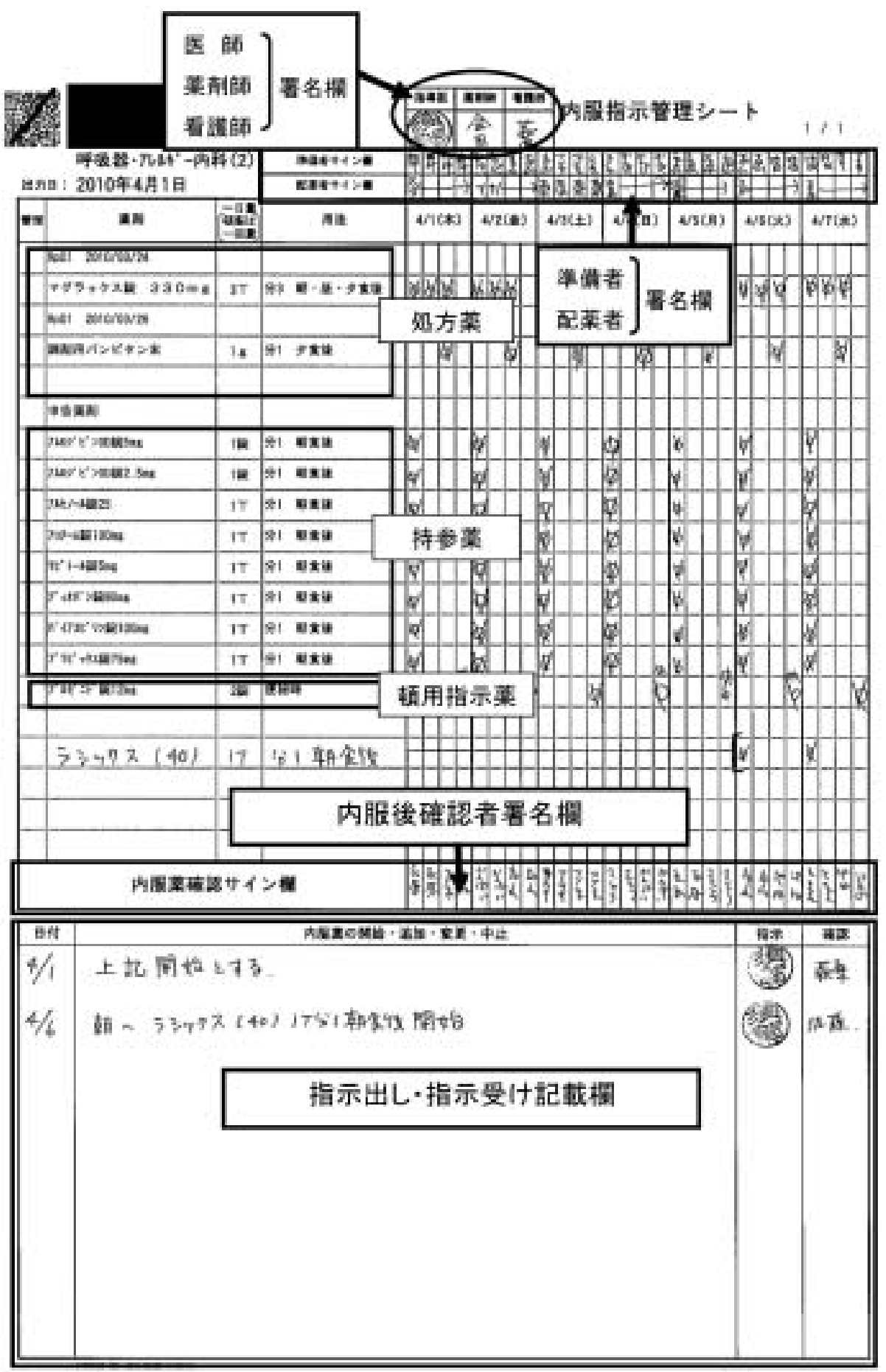

図 3 . 持参薬，頓用指示薬および処方薬をすべて反映した 1週間分の内服指示書

結果

1. 持参薬入カシステムの变更による持参薬情報の精度 変化

2008年には 4 週間で 1755 枚，2009年には 1564 枚の 内服指示書が作成されており，手書きによる追加がある 指示書は光れ枈れ893枚(51\%)および826枚(53\%)で， 手書き追加有無の比率に変化はみられなかった . また ,
持参薬の入力を行った職員の職種は, 薬剂師による入力 比率が高くなった(表 1). 一方，薬㓢の規格の記載に不 備がある指示書は乥れ艺れ 111枚(6.3\%)から 38 枚(2.4 $\%)$ へと有意に減少した $(\mathrm{P}<0.01)$. また, 薬名などに記 載の誤りがある指示書はシステムに不慣れな医師が手書 きにより追加指示をしたもののみであり，弚の数は 26 枚(1.5\%)から 13 枚(0.8\%)に減少する傾向が認められた $(P=0.08)($ 表 1$)$. 
2. 医師による内服指示書への署名割合

医師による内服指示書の指示出し確認の署名は 2007 年 6 月には 73.8\% であったが，2009年 3 月には完全に 実施されていた $(P<0.01)$

\section{考察}

高齢化社会の進行や医療の高度専門化などにより，患 者が長期間にわたって複数の医療機関を受診し，入院時 に他医療機関からの処方薬を持参する機会が多くなっ た．近年では入院患者の $80 \%$ 程度に持参薬があり ${ }^{1-6)}$, 半数以上が当該医療期間以外で処方された薬であると報 告されている6).

入院時に持参薬を継続使用させるか当該医療機関で新 たに処方するかは医療機関の方針によって異なるが，入 院前と同樣の薬物療法を継続するためには正確な持参薬 調査が不可欠である.しかし，患者の持参薬は必ずしも 当該医療機関の採用医薬品であるとは限らず，また院外 処方の場合は後発品へ変更されていることもあるため， 十分な知識を持った薬斉師が持参薬の鑑別を行うことが 望ましい.

持参薬の情報を他の医療従事者に確実に伝えるために
は文書の作成が必須であり，持参薬管理シートの作成を 支援するさまざまな方法が検討されている．国内で市販 されているすべての医薬品が持参薬となり得るため，持 参薬の名称や規格を正確に伝達するためには, 全医薬品 をマスターデータとする入力支援システムの利用が望ま しい, $2,12,14)$. 本研究でも, 全医薬品を検索可能で処方 オーダリングと同樣に3文字一致検索により入力できる システムを採用したところ, 規格の記載不備を有意に減 少させることができた . なお , システム変更後の持参薬 入力システムへ入力した場合は薬名などの誤記載はなく なったが, 2009 年 1 月はシステム変更と研修医師の ローテーションが重なり医師への浸透が完全ではなく， 依然として手書きによる追加指示が継続していたため有 意な減少にはならなかった，現在では，初回に医師より 手書きで追加される指示を除き，規格の欠落はほとんど みられなくなっている .メニューに表示された医薬品名 から選択して入力する方式であるため，医薬品の名称の 誤りも極めて少なくなった．薬剂師が持参薬の鑑別に関 わることで持参薬情報の精度は向上するが , 入院中の薬 物療法は内服指示書により実施されることが多いので， 持参薬情報を入院後の薬物療法に反映させるためには， 内服指示書に正確に転記する必要がある.しかしなが

表 1 . 内服指示書の作成状況

\begin{tabular}{|c|c|c|c|c|c|}
\hline & \multicolumn{2}{|c|}{2008 年 $11 \sim 12$ 月 } & \multicolumn{3}{|c|}{2009 年 1 2 月 } \\
\hline & (枚) & $(\%)$ & (枚) & $(\%)$ & \\
\hline 総枚数 & 1755 & & 1564 & & \\
\hline 手㶳き追加がある & 893 & 50.9 & 826 & 52.8 & $\mathrm{P}=0.27$ \\
\hline 規格の記載に不備 & 111 & 6.3 & 38 & 2.4 & $\mathrm{P}<0.01$ \\
\hline 薬名などの䛊記載 & 26 & 1.5 & 13 & 0.8 & $\mathrm{P}=0.08$ \\
\hline 入力した職種 & (件) & $(\%)$ & (件) & $(\%)$ & \\
\hline 総件数 & 2367 & & 2172 & & $\mathrm{P}<0.01$ \\
\hline 垁師 & 857 & 36.2 & 696 & 32 & \\
\hline 薬剂師 & 1503 & 63.5 & 1476 & 68 & \\
\hline その他 & 7 & 0.3 & 0 & 0.0 & \\
\hline
\end{tabular}


ら, 内服指示書への転記の際の誤りは非常に高率で起こ $り^{22}$ ，内服指示書の作成にも薬剂師が関与する必要があ ると考えられる . また , 入カシステムの改善により誤入 カや規格不備を回避しやすいシステムになったことで医 師の依頼を受けた薬斉師が入力するケースか増えた . 近 年 , 医師の負担軽減のため医師以外の職種か処方入力な どの作業を補助することが求められているが，医師が容 易に再確認できるシステムの設計に薬斉師か関与し，医 師が安心して他職種に任せられる環境を整えることの重 要性が示唆された。

これまで報告されている市販のソフトウェアを利用し

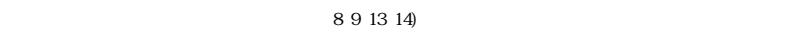
シートを処方データと別途に扱うか，もしくはいずれか のデータを他方に転記する必要があるため, 転記ミスの 危険性がある . 持参薬情報を電子カルテに直接記載する 方式2 10)であれば关の危険性は防止できるが，持参薬管 理シートをスキャナで取り込んで電子カルテに貼りつけ る方式 ${ }^{10}$ では，処方情報と連動させることは困難である．

そこで, 当院では持参薬入カシステムと処方データを 病院情報システムで統合し，1枚の内服指示書を作成 し，これを週 1 回更新することにより，常に最新の薬物 治療の状況が反映されるようにした . 指示書には指示出 しをした医師の他，指示受けした看護師および薬阂師， 与薬準備や服薬確認をした看護師または薬阁師も署名す るので, 薬物治療の確実な記録となる .

内服指示書を医師による指示書として運用するために は，医師による指示か確認できることが重要であるが， 2007 年に安全管理室を通じて診療科に徹底を図った結 果，現在でも医師による指示出しか確実に行われている ことが確認できた .

本システムでは，持参薬の情報も処方オーダと同樣の 形式で取り扱われているため, 処方薬と持参薬との薬物 間相互作用をチェックすることも可能である . しかしな がら，現時点では相互作用の重篤度を反映させたマス ターデータが作成されておらず，添付文書上で併用注意 とされたすべての組みあわせについて警告が出るため， 実用的ではない．より確実に患者の安全性を確保するた めには，市販されているすべての医薬品を対象とする相 互作用データの整備や用量の上限・下限のデータなどの 充実か望まれる . 将来は, 注射指示や検査なども含めた 統一的な指示書を作成することにより，すべての医療従 事者が患者の治療全体を把握できることが望ましいと考 えている。

\section{引用文献}

1) 塩谷明子, 高橋佳子, 篠原由貴, 木村知行, 橋本肇, 門 林宗男，薬剂管理指導業務における持参薬チェックの必
要性, 日本病院薬斉師会杂隹誌, 41, 1135-1137 (2005).

2）尾上雅英, 赤澤麻衣子, 寺田智祐, 若杉博子, 石津雅弘, 乾賢一, 腫瘍外科病棟における持参薬チェックと光の評 価 - 薬剤師による患者面談から内服指示簿までの照合を 通して一，医療薬学，32，424-428 (2006).

3）伊勢雄也, 菅谷量俊, 高田未来, 内田亨, 大下順子, 川 田桂子, 中嶋基広, 片山志郎, 菊池有道, 小森邦子, 千 田英理子, 長谷川幸子, 日本医科大学附属病院における 持参薬チェック業務並びに医療費の節減効果，日本病院 薬斉師会雑誌，42，667-669 (2006).

4) 栃倉尚広, 福島栄, 金子睦志, 鏑木盛雄, 加島陽二, 眼 科手術目的の短期入院患者における持参薬管理システ ム, 日本病院薬斉師会雑誌, 42, 381-384 (2006).

5) 門村将太, 鈴木智子, 浅野尚, 福田由布子, 吉田麻里, 鈴木聖奈子, 竹内美奈, 志賀隆博, 井筝達也, 竹本 功, 持参薬等管理業務の確立と薬剂師の役割, 医療薬学, 34, 671-676 (2008).

6) 橋本陽，小出哲朗，沢部公子，入院患者における持参薬 チェックおよびお薬手帳の活用による安全管理としての 有用性の検討, 日本病院薬剂師会雑誌, 45, 798-800 (2009).

7) 山下梨沙子, 井門敬子, 岡田彰男, 森岡淳子, 浦本さや か, 池川嘉郎, 末丸克矢, 荒木博陽, 薬斉師による入院 時初回面談業務の現状と持参薬管理の重要性, 日本病院 薬斉師会雑誌，43，520-523 (2007).

8）杉山留美子, 星野輝彦, 桜間博文, 塩津和則, 持参薬管 理業務における誤薬防止への取り組み，日本病院薬斉師 会雑誌，44，99-101 (2008).

9)鈴木智子, 福田由布子, 門村将太, 浅野尚, 吉田麻里, 鈴木聖奈子, 竹内美奈, 志賀隆博, 井筝達也, 竹本 功, 入院時患者持参薬確認と EXCEL を用いた管理表作成プ ログラムの構築，医療薬学，35，177-182 (2009).

10)田崎正信, 平野和裕, 齋田哲也, 藤戶博, 入院患者持参 薬の効率的なチェックシステム, 医療薬学 $, 32,1236-$ 1241 (2006).

11）原千恵子, 小枝正吉, 山下恭範, 藤丸サヤ力, 大滝康一, 森田真由美，小野尚志，山田武宏，板坦健太郎，須野あ づみ, 利岡果美, 石王応知, 村上知子, 朴紘慶, 須野 学, 粟屋敏雄, 小川聡, 高橋賢尚, 山本久仁子, 板垣祐 一, 千葉薰, 三好敏之, 笠原直邦, 藤田育志, 田崎嘉一, 早勢伸正, 松原和夫, 入院日持参薬チェックは医療の安 全性に寄与する - 持参薬チェック管理薬斉師の役割 - 医 療薬学 , 31, 360-366 (2005).

12）遠原大地, 井上真, 槇原洋子, 柴田七奈, 野田佳子, 片 桐文彦，伊東弘樹，武山正治，リスク回避を目的とした 入院時持参薬チェックシステムの構筑, 医療薬学, 33 , 762-767 (2007).

13) 中村郁子, 加茂まどか, 佐藤香織, 穂積雅人, 久道周彦, 後藤順一, 題野成康, 入院時持参薬の分析結果および医 療スタッフからの評価, 医療薬学 , 34, 522-529 (2008).

14）渡邊裕之, 中井由佳, 持参薬鑑別報告書作成支援システ ムの構築と評価, 医療薬学, 33, 913-919 (2007). 